\title{
CORRIGENDUM
}

\section{SMN2 splice modulators enhance U1-pre-mRNA association and rescue SMA mice}

James Palacino, Susanne E Swalley, Cheng Song, Atwood K Cheung, Lei Shu, Xiaolu Zhang, Mailin Van Hoosear, Youngah Shin, Donovan N Chin, Caroline Gubser Keller, Martin Beibel, Nicole A Renaud, Thomas M Smith,

Michael Salcius, Xiaoying Shi, Marc Hild, Rebecca Servais, Monish Jain, Lin Deng, Caroline Bullock, Michael McLellan,

Sven Schuierer, Leo Murphy, Marcel J J Blommers, Cecile Blaustein, Frada Berenshteyn, Arnaud Lacoste,

Jason R Thomas, Guglielmo Roma, Gregory A Michaud, Brian S Tseng, Jeffery A Porter, Vic E Myer, John A Tallarico,

Lawrence G Hamann, Daniel Curtis, Mark C Fishman, William F Dietrich, Natalie A Dales \& Rajeev Sivasankaran

Nat. Chem. Biol. 11, 511-517 (2015); published online 1 June 2015; corrected online 15 July 2015

The authors forgot to include a description of the measurement of SMN protein levels in tissue samples in the Online Methods. This description has been included in the HTML and PDF versions of the article.

\section{CORRIGENDUM}

\section{Sterol metabolism controls $\mathrm{T}_{\mathrm{H}} 17$ differentiation by generating endogenous ROR $\gamma$ agonists}

Xiao Hu, Yahong Wang, Ling-Yang Hao, Xikui Liu, Chuck A Lesch, Brian M Sanchez, Jay M Wendling, Rodney W Morgan, Tom D Aicher, Laura L Carter, Peter L Toogood \& Gary D Glick

Nat. Chem. Biol. 11, 141-147 (2015); published online 5 January 2015; corrected after print 15 July 2015

In the version of this article initially published, the zymosterol and zymostenol structures shown in Figure 3a were depicted with a double bond at $\mathrm{C} 14-\mathrm{C} 15$, where there should have been a single bond. The error has been corrected in the HTML and PDF versions of the article.

\section{ERRATUM}

\section{Hydrolysis of 2'3'-cGAMP by ENPP1 and design of nonhydrolyzable analogs}

Lingyin Li, Qian Yin, Pia Kuss, Zoltan Maliga, José L Millán, Hao Wu \& Timothy J Mitchison

Nat. Chem. Biol. 10, 1043-1048 (2014); published online 26 October 2014; corrected after print 29 January 2015 and 15 July 2015.

In the version of this article published on 29 January 2015, in Figure 4 the hydroxyl group was depicted in the $3^{\prime}$ position on the deoxyribose ring of the cyclic dinucleotide precursor to $3^{\prime} 3^{\prime}$-cGAMP rather than in the $2^{\prime}$ position and the R group was in the $2^{\prime}$ position rather than in the $3^{\prime}$ position. This error has been corrected in the HTML and PDF versions of the article.

\section{ERRATUM}

\section{Structural basis of enzymatic benzene ring reduction}

Tobias Weinert, Simona G Huwiler, Johannes W Kung, Sina Weidenweber, Petra Hellwig, Hans-Joachim Stärk, Till Biskup, Stefan Weber, Julien J H Cotelesage, Graham N George, Ulrich Ermler \& Matthias Boll

Nat. Chem. Biol. doi:10.1038/nchembio.1849; corrected online 7 July 2015

In the version of this article initially published online, the final intermediate in Figure 1a was originally depicted as a fully delocalized radical anion, which was incorrect. The error has been corrected for the print, PDF and HTML versions of this article.

\section{CORRIGENDUM}

\section{Local and macroscopic electrostatic interactions in single $\alpha$-helices}

Emily G Baker, Gail J Bartlett, Matthew P Crump, Richard B Sessions, Noah Linden, Charl F J Faul \& Derek N Woolfson

Nat. Chem. Biol. 11, 221-228 (2015); published online 9 February 2015; corrected after print 5 June 2015

In the version of this article initially published, two pairs of citations of Figures $4 \mathrm{~b}$ and $4 \mathrm{c}$ were inadvertently switched. The errors have been corrected in the HTML and PDF versions of the article. 